\title{
KONSEP PENERAPAN RESTORATIVE JUSTICE TERHADAP TINDAK PIDANA YANG DILAKUKAN OLEH ANAK PERSPEKTIF HUKUM ISLAM
}

\author{
Akhmad Shodikin \\ Fakultas Syariah dan Ekonomi Islam \\ IAIN Syekh Nurjati Cirebon \\ J1. Perjuangan By Pass Sunyaragi Cirebon \\ Email: shodikin73@gmail.com \\ Abstrak
}

\begin{abstract}
Anak adalah bagian yang tidak terpisahkan dari keberlangsungan hidup secara tegas dinyatakan bahwa negara menjamin hak setiap anak atas keberlangsungan hidup, tumbuh, dan berkembang serta atas perlindungan dari kekerasan dan diskriminasi. Perlindungan terhadap anak tidak hanya diberikan kepada anak yang menjadi korban tindak pidana, namun juga kepada anak yang menjadi pelaku tindak pidana,sehingga dalam proses hukum apalagi dalam memberikan putusan pidana seharusnya juga mempertimbangkan masa depan si anak karena bagi suatu negara, anak merupakan harapan masa depan negara. Terhadap anak yang melakukan tindak pidana ini juga dikenai sanksi pidana. Berbicara mengenai pemidanaan terhadap anak sering menimbulkan perdebatan, karena masalah ini mempunyai konsekuensi yang sangat luas baik menyangkut diri prilaku maupun masyarakat. Pemidanaan merupakan unsur dari hukum pidana,dimana pemidanaan itu mempunyai akibat negatif bagi orang yang diberikan sanksi pidana. Seiring dengan Undang-undang Nomor 11 Tahun 2012. Sedangkan efektivitas penerapan sanksi terhadap anak dalam perspektif restorative jusitce di Wilayah Hukum Polres Mataram adalah cukup efektif karena korban, pelaku dan masyarakat puas dengan penyelesaian secara restorative justice dan mengingat lahirnya Undang-undang Nomor 11 Tahun 2012 Tentang Sistem Peradilan Pidana Anak.
\end{abstract}

Kata Kunci :Pidana, Anak, Restorative Justice.

\begin{abstract}
Children are an inseparable part of survival which expressly states that the state guarantees the rights of every child to survival, growth and development and to protection from violence and discrimination. Protection of children is not only given to children who are victims of criminal acts, but also to children who are perpetrators of crimes, so that in the legal process especially in giving criminal decisions should also consider the future of the child because for a country, children are the hope of the future country. The child who commits this crime is also subject to criminal sanctions. Talking about criminal prosecution of children often causes debate, because this problem has very broad consequences both regarding selfbehavior and society. Criminal punishment is an element of criminal law, where the sentence has a negative effect on the person given criminal sanctions. In line with Law Number 11 of 2012. While the effectiveness of the application of sanctions on children in the perspective of restorative jusitce in the Legal Territory of Mataram Police is quite effective because the victims, perpetrators and the community are satisfied with the restorative justice settlement and considering the birth of Law Number 11 of 2012 About the Child Criminal Justice System.
\end{abstract}

Keywords: Criminal, Child, Restorative Justice. 



\section{A. Latar Belakang Masalah}

Perlindungan anak merupakan bagian dari pembangunan Nasional. Melindungi anak adalah melindungi manusia, dan membangun manusia seutuh mungkin. Hal ini tercermin pada hakekat pembangunan nasional yaitu membangun manusia Indonesia seutuhnya yang berbudi luhur. Mengabaikan masalah perlindungan anak berarti tidak akan memantapkan pembangunan nasional. Akibat tidak adanya perlindungan anak akan menimbulkan berbagai permasalahan sosial yang dapat mengganggu penegakan hukum, ketertiban, keamanan, dan pembangunan nasional. $^{1}$

Kita Sepakat Bahwa Anak adalah bagian warga Negara yang harus dilindungi karena mereka merupakan generasi bangsa yang dimasa yang akan datang akan melanjutkan kepemimpinan bangsa Indonesia. Setiap anak selain wajib mendapatkan pendidikan formal seperti sekolah, juga wajib mendapatkan pendidikan moral sehingga meraka dapat tumbuh menjadi sosok yang berguna bagi bangsa dan negara. Sesuai dengan ketentuan Konvensi Hak Anak (Convention on the Rights of the Child) yang diratifikasi oleh pemerintah Indonesia melalui Keputusan Presiden Nomor 36 Tahun 1990, kemudian juga dituangkan dalam Undang- Undang Nomor 4 Tahun 1979 tentang Kesejahteraan Anak dan Undang - Undang Nomor 23 Tahun 2002 tentang Perlindungan Anak dan Undang-Undang Nomor 11 Tahun 2012 tentang Sistem Peradilan Pidana Anak yang kesemuanya mengemukakan prinsip-prinsip umum perlindungan anak, yaitu non diskriminasi, kepentingan terbaik bagi

1 Romli atmasasmita, Peradilan Anak Di Indonesia (Bandung: Mandar Maju, 1997), . 166 anak, kelangsungan hidup dan tumbuh kembang dan menghargai partisipasi anak.

Restorative

Justice

diimplementasikan ke dalam UndangUndang Nomor 11 Tahun 2012 tentang Sistem-Sistem Peradilan Pidana Anak yang di dalamnya menjunjung tinggi harkat dan martabat anak. Penerapan Restorative Justice terhadap tindak pidana penganiayaan dan atau pengeroyokan oleh anak di bawah umur merupakan suatu teori yang sangat menarik untuk dikaji dan diteliti karena selain membahas tentang keadilan, Restorative Justice juga menjadikan suatu sistem peradilan yang seimbang karena dapat memberikan perlindungan dan penghargaan serta kepentingan antara si korban dan pelaku yang berkonflik.

Penghukuman bagi pelaku

Tindak Pidana Anak tidak kemudian mencapai keadilan bagi korban, mengingat dari sisi lain masih meninggalkan permasalahan tersendiri yang tidak terselesaikan meskipun pelaku telah dihukum. Melihat prinsip-prinsip tentang perlindungan anak terutama prinsip mengutamakan kepentingan terbaik bagi anak maka diperlukan proses penyelesaian perkara anak diluar mekanisme pidana atau biasa disebut diversi. Institusi penghukuman bukanlah jalan untuk menyelesaikan permasalahan anak karena justru di dalamnya rawan terjadi pelanggaran-pelanggaran terhadap hak anak. Karena itu dibutuhkan suatu acara dan prosedur sistem yang dapat mengakomodasi penyelesaian perkara yang salah satunya adalah dengan menggunakan pendekatan keadilan restoratif, melalui suatu pembaharuan hukum yang tidak sekedar mengubah undang-undang semata tetapi juga memodifikasi sistem peradilan pidana yang ada, 
sehingga semua tujuan yang dikehendaki oleh hukumpun tercapai. Salah satu bentuk mekanisme Restorative Justice tersebut adalah dialog yang dikalangan masyarakat Indonesia lebih dikenal dengan sebutan "musyawarah untuk mufakat". Sehingga diversi khususnya melalui konsep Restorative Justice menjadi suatu pertimbangan yang sangat penting dalam menyelesaikan perkara pidana yang dilakukan oleh anak.

\section{B. Keadilan Resorative Justice}

\section{Justice}

1. Pengertian Restorative

Konsep restoratif justice merupakan konsep di mana korban dan pelaku sama-sama dilibatkan dalam penyelesaian masalah yang menimbulkan kerguian bagi korban. Sehingga konsep ini secara konstruktif akan menyadarkan anak yang melaksanakan tindak pidana akan kesalahan mereka, dengan kata lain pelaku nantinya akan menyadari bahwa pidana adalah kewajiban bukan pembalasan. $^{2}$

Menurut Muladi, restoratif justice atau keadilan restoratif adalah sebuah teori yang menekankan pada memulihkan kerugian yang disebabkan atau ditimbulkan oleh perbuatan pidana. Memulihkan kerugian ini akan tercapai dengan adanya proses-proses kooperatif yang mencakup semua pihak yang berkepentingan. ${ }^{3}$ Konsep keadilan restoratif lebih menitikberatkan pada kondisi terciptanya keadilan dan keseimbangan bagi pelaku tindak pidana dan korbannya sendiri.

\footnotetext{
2 Nurnaningsih Amriani, "Penanganan Perkara Anak Melalui Konsep Diversi dan Restoratif Justice", Majalah Hukum Varia Peradilan, Nomor 323, (Jakarta: IKAHI, 2012), . 72.

3 Muladi, Kapita Selekta Hukum Pidana,
} (Semarang: Universitas Diponegoro, 1995), . 125.
Mekanisme tata cara peradilan pidana yang berfokus pada pemidanaan diubah menjadi proses dialog dan mediasi untuk menciptakan kesepakatan atas penyelesaian perkara pidana yang lebih adil dan seimbang bagi pihak korban dan pelaku. ${ }^{4}$

Menurut Eva Achjani Zulfa, keadilan restoratif adalah sebuah konsep pemikiran yang merespon pengembangan sistem peradilan pidana dengan menitik beratkan pada kebutuhan pelibatan masyarakat dan korban yang dirasa tersisihkan dengan mekanisme yang bekerja pada sistem peradilan pidana yang ada pada saat ini. Berbeda dengan sistem yang sekarang ada, pendekatan ini menitikberatkan pada adanya partisipasi langsung pelaku, korban dan masyarakat dalam proses penyelesaian perkara pidana. ${ }^{5}$

Pelaksaan keadilan restoratif bertujuan memberdayakan korban, dan mendorong pelaku agar memperhatikan pemulihan. Keadilan restoratif mementingkan terpenuhinya kebutuhan material, emosional dan sosial sang korban. Keberhasilan keadilan restoratif diukur oleh sebesar apa yang telah dipulihkan pelaku, bukan diukur oleh seberat apa pidana yang dijatuhkan hakim. Jadi, sedapat mungkin pelaku dikeluarkan dari proses pidana dan dari penjara. Tapi seperti dikatakan Kent Roach, keadilan restoratif bukan hanya memberikan alternatif bagi penuntutan dan pemenjaraan,

4 Septa Candra, Restoratif Justice: Suatu Tinjauan terhadap Pembaharuan Hukum Pidana di Indonesia, "Jurnal RechtsVinding Media Pembinaan Hukum Nasional, Vol. 2 No. 2, (Jakarta: Pusat Penelitian dan Pengembangan Sistem Hukum Nasional, 2013), . 264.

5 Achjani Zulfa, Eva. Keadilan Restoratif di Indonesia: Studi tentang Kemungkinan Penerapan Pendekatan Keadilan Restoratif dalam Praktek Penegakkan Hukum Pidana. (Depok: Disertasi FH UI. 2009). . 1 
melainkan juga meminta tanggungjawab pelaku. ${ }^{6}$

Pendekatan yang digunakan untuk mewujudkan keadilan restoratif adalah mengupayakan proses mediasi antara korban dan pelaku, pertemuan dan dialog antara korban dan pelaku yang melibatkan keluarga dan masyarakat luas, dan menumbuhkan kesadaran pelaku dan korban. Semangat utama keadilan restoratif bukan hanya untuk mengadili atau menghukum pelaku melainkan untuk mereparasi dan merestorasi korban dan pelaku. Maka nilai keadilan restoratif terletak pada dialog (dialogue), kesepahaman (mutuality), penyembuhan (healing), perbaikan (repair), penyesalan dan tobat (repentance), tanggungjawab (responsibility), kejujuran (honesty) dan ketulusan (sincerity). ${ }^{7}$

$$
\text { Restoratif justice telah }
$$

berkembang secara global di seluruh dunia. Di banyak negara restoratif justice menjadi satu dari sejumlah pendekatan penting dalam kejahatan dan keadilan yang secara terus menerus dipertimbangkan dalam sistem peradilan dan Undang-Undang. Sesuai dengan penyebaran proses ini di seluruh dunia maka timbul beberapa inovasi yang memang terbuka untuk restoratif justice. Seperti yang dipraktekkan di Amerika Serikat, Canada, Inggris, Belgia, Belanda dan beberapa negara lainnya. Beberapa negara tersebut korban dan pelaku bertemu di penjara. ${ }^{8}$

$$
\text { Dalam keadilan restoratif }
$$

6 Eriyantouw Wahid, Keadilan Restoratif Justice dan Peradilan Konvensional Dalam Hukum Pidana, (Jakarta: Trisakti, 2009), . 4.

7 S. Atalim, Keadilan Restoratif sebagai Kritik Inheren terhadap Pengadilan LegalKonvensional", Jurnal Rechts Vinding Media Pembinaan Hukum Nasional, Vol. 2 No. 2, (Jakarta: Pusat Penelitian dan Pengembangan Sistem Hukum Nasional, 2013), . 145.

${ }^{8}$ Marlina, Op. Cit, . 196. korban diperhitungkan martabatnya, dan pelaku harus bertanggungjawab dan diintegrasikan kembali dalam komunitasnya. Pelaku dan korban berkedudukan seimbang dan saling membutuhkan, karena itu harus dirukunkan. Posisi perkara dari keadilan restoratif harus diubah, bukan lagi demi kepentingan ketertiban, melainkan demi kepentingan korban beserta pemulihan segi materi dan psikisnya. Jadi, yang ingin diwujudkan dalam keadilan restoratif justice adalah menghindarkan pelaku dari pemenjaraan, dan harus bertanggungjawab atas perbuatannya. ${ }^{9}$

Konsep ini selaras dengan pendekatan restoratif justice, karena tujuan diversi sesuai Pasal 6 UU SPPA adalah:

a. Mencapai perdamaian antara korban dan anak

b. Menyelesaikan perkara anak di luar proses peradilan

c. Menghindarkan anak dari perampasan kemerdekaan

d. Mendorong masyarakat untuk berpartisipasi, dan

e. Menanamkan rasa tanggungjawab kepada anak.

Keadilan restoratif merupakan konsep tradisional yang telah dipraktikkan di beberapa negara khususnya di belahan dunia Timur. Konsep ini diyakini sebagai alternatif dalam rangka mengurangi ekses yang tidak diinginkan sebagai akibat dari diterapkannya sistem peradilan pidana formal. Konsepsi tersebut telah berjalan dan diterapkan di negaranegara lain dan diyakini sebagai alternatif untuk menghindarkan ekses negatif penggunaan sistem formal lembaga peradilan yang terkadang memproduksi sesuatu yang sifatnya unwelfare guna melindungi

\footnotetext{
${ }^{9}$ Eriyantouw Wahid, Op. Cit, . 2.
} 
kepentingan hukum para pihak. ${ }^{10}$

Menurut $\mathrm{PBB}$, program keadilan restoratif justice adalah program yang menggunakan proses restoratif dengan sasaran untuk mencapai hasil yang diinginkan. Tujuan utama model tersebut adalah untuk memulihkan kedamaian dan hubungan yang rusak melalui celaan terhadap pelaku jahat dan menguatkan nilai-nilai yang hidup dalam masyarakat. para korban diperhatikan kebutuhannya dan para pelaku didorong untuk bertanggungjawab. ${ }^{11}$

Keadilan restoratif muncul karena dipicu ketidakpuasan atas Sistem Peradilan Pidana konvensional dan berakar pada praktik-praktik pribumi. Keadilan restoratif digunakan terhadap kejahatan, disiplin dalam sekolah dan pelbagai konflik lain antara warga dengan pemerintah, Komisi Traktat Waitangi di New Zealand. $^{12}$

Keadilan restoratif mengacu pada cara-cara tradisional, adat dan agama yang ada berkaitan dengan konflik, namun efektifitas praktik keadilan restorative sering bergantung pada sistem peradilan pidana yang berfungsi dengan baik dan kredibel. Penekanan pembaharuan pada keadilan restoratif sering didasarkan pada pandangan bahwa negara tidak lagi dianggap sebagai satu-satunya sumber untuk mewujudkan keadilan yang efektif dan adil. ${ }^{13}$ Konsep keadilan restoratif dapat juga dipandang sebagai pencarian alternatif baru dalam menyelesaikan kasuskasus secara rekonsiliatif dengan

10 Muhammad Ali Zaidan, Menuju Pembaharuan Hukum Pidana, (Jakarta: Sinar Grafika, 2015), . 241.

\footnotetext{
11 Muhammad Ali Zaidan, Menuju Pembaharuan Hukum Pidana, . 241.

12 Muhammad Ali Zaidan, Мепијu

Pembaharuan Hukum Pidana, . 242.

13 Muhammad Ali Zaidan, Menuju Pembaharuan Hukum Pidana,,, . 248.
}

melibatkan korban, pelaku, dan masyarakat. Konsep ini berhasil efektif menyelesaikan beberapa kasus mulai yang digolongkan ringan sampai kepada kasus besar seperti pembunuhan. $^{14}$

\section{Kebijakan Melalui Konsep Keadilan Restoratif}

Menurut Howard Zehr, keadilan restoratif dimaknai sebagai proses untuk melibatkan, memungkinkan keterlibatan pihak-pihak yang lebih luas, yakni para pihak yang mempunyai kepentingan atas suatu pelanggaran yang spesifik. Kemudian secara bersama, mengidentifikasi dan mengarahkan kerugian, kebutuhan, dan kewajiban dalam rangka menyembuhkan dan menempatkan hak para pihak sebagai titik yang mungkin dituju untuk diselesaikan. Kemudian menurut Sharpe keadilan restoratif memiliki karakteristik yang fundamental dengan beragam nilai yang disebut dengan pengikutsertaan (partisipasi), demokrasi, tanggung jawab, pemulihan, keamanan, penyembuhan, dan reintegrasi. ${ }^{15}$

Selanjutnya menurut United Nations Office on Drugs and Crime (UNODC), keadilan restoratif merujuk pada proses untuk memecahkan tindak pidana (kejahatan) dengan memusatkan pada perbaikan kerugian (luka) korban, menetapkan pelaku bertanggung jawab atas tindakannya, dan melibatkan masyarakat dalam menyelesaikan konflik yang terjadi tersebut. Dengan demikian proses restoratif merupakan setiap proses yang mana korban dan pelaku atau individu lainnya atau anggota komunitas yang terpengaruh oleh suatu tindak pidana, mengambil

\footnotetext{
14 Muhammad Ali Zaidan, Мепијu Pembaharuan Hukum Pidana, . 123.

15 Ann Skelton \& Boyane Tshehla, Child Justice in South Africa, Institute for Security Studies, Monograph 150 September 2008,
} 
bagian bersama secara aktif dalam penyelesaian berbagai masalah yang muncul akibat tindakan pidana tersebut dengan bantuan fasilitator. ${ }^{16}$

Diversi dapat dimaknai sebagai upaya menjauhkan suatu kasus dengan kriteria tertentu dari proses peradilan pidana formal menuju ke arah dukungan komunitas untuk menghindari dampak negatif yang diakibatkan oleh proses peradilan pidana. Pada dasarnya tindakan diversi dapat dilakukan pada tahapan manapun dalam proses peradilan pidana. Penerapan diversi bergantung pada keputusan polisi, jaksa, pengadilan, atau badan-badan sejenis. Namun demikian, dalam banyak sistem keputusan diversi dibuat pada awal proses peradilan pidana. Dengan demikian diversi merupakan kanalisasi kasus tertentu untuk dijauhkan dari sistem peradilan pidana yang pada umumnya berdasarkan kondisi-kondisi tertentu yang menempatkan pelaku pada posisi yang sulit (fait accompli). ${ }^{17}$

Lebih jauh, menurut Van Rooyen, diversi dapat juga didefinisikan sebagai prima facie pengalihan suatu kasus dari upaya penyelesaian melalui proses persidangan yang normal. Hal ini berimplikasi bahwa tuntutan kepada pelaku berdasarkan kondisionalitas tertentu dapat ditarik mundur atau dihentikan. Selanjutnya pelaku harus berpartisipasi pada program khusus atau memulihkan korban. Diversi dapat juga disebut penyelesaian di luar pengadilan (out-of-court settlement) di mana tuntutan terhadap terdakwa dihentikan atau dicabut, namun sebagai gantinya tersangka harus

16 United Nations Office on Drugs and Crime (UNODC), Handbook on Restorative Justice Programmes, op.cit

${ }^{17}$ United Nation Office in Drugs and Crime, Cross-Cutting Issues: Juvenile Justice, op.cit mentaati persyaratan-persyaratan yang disepakati oleh para pihak.

Pada suatu proses restoratif, kepentingankepentingan korban adalah jauh bersifat sentral dibanding dalam proses-proses hukum acara pidana saat ini. Di beberapa negara telah mengadopsi suatu legislasi yang menetapkan hak-hak prosedural yang dimiliki oleh korban sepanjang suatu proses hukum acara pidana atau proses dari hukum acara pidana remaja. ${ }^{18}$

\section{B. Perlindungan Hukum Terhadap Anak di Bawah Umur}

\section{Pengertian Anak}

Pengertian anak dalam

kaitannya dengan perilaku delinkuensi anak, biasanya dilakukan dengan mendasarkan pada tingkatan usia, dalam arti tingkat usia berapakah seorang dapat dikategorikan sebagai anak. 19

Anak memiliki karakteristik khusus (spesifik) dibandingkan dengan orang dewasa dan merupakan salah satu kelompok rentan yang haknya masih terabaikan, oleh karena itu hak-hak anak menjadi penting diprioritaskan. ${ }^{20}$

Secara nasional definisi anak menurut perundang-undangan, diantaranya menjelaskan anak adalah merupakan amanah dan karunia Tuhan Yang Maha Esa yang memiliki harkat dan martabat sebagai manusia seutuhnya dan pasal 1 Undang-undang

18 Rufinus Hitmaulana Hutauruk, Penanggulangan Kejhatan Korporasi Melalui Pendekatan Restoratif Suatu Trobosan Hukum, (Jakarta: Sinat Grafika, 2014), . 264.

19 Paulus Hadisuprapto, Delinkuensi Anak Pemahaman dan Penanggulangannya, (Malang: Selaras, 2010), .11

${ }^{20}$ PERMEN Pemberdayaan Perempuan dan Perlindungan Anak R.I. Nomor 15 Tahun 2010, Pedoman Umum Penanganan Anak Yang Berhadapan Dengan Hukum, Kementrian Pemberdayaan Perempuan dan Perlindungan Anak R.I. 
Republik Indonesia Nomor 23 Tahun 2002 tentang Perlindungan Anak, anak adalah seseorang yang belum berusia 18 tahun dan bahkan masih di dalam kandungan. ${ }^{21}$

Definisi anak yang ditetapkan perundang-undangan berbeda dengan definisi menurut hukum islam dan hukum adat. Menurut hukum islam dan hukum adat sama-sama menentukan seseorang masih anakanak atau sudah dewasa bukan dari usia anak. ${ }^{22}$ Hal ini karena masingmasing anak berbeda usia untuk mencapai tingkat kedewasaan. Hukum islam menentukan definisi anak dilihat dari tanda-tanda pada seseorang apakah seseorang itu sudah dewasa atau belum. Artinya seseorang dinyatakan dewasa sebagai anak apabila anak tersebut belum memiliki tanda-tanda yang dimiliki oleh orang dewasa sebagaimana ditentukan dalam hukum Islam.

Pasal 1 angka 1 menyatakan bahawa "anak adalah seseorang yang belum berusia 18 (delapan belas) tahun, termasuk anak yang masih dalam kandungan". Dari pengertian anak sebagaimana yang dimaksud dalam pasal 1 angka 1 Undangundang tersebut dapat diketahui bahwa seseorang dapat disebut anak jika memenuhi syarat sebagai berikut: ${ }^{23}$

a. Belum berusia 18 (delapan belas) tahun;

Frasa "Belum berusia 18 (delapan belas) tahun" dalam pasal 1 angka 1 Undang-undang Nomor 35 tahun 2014 tentang perubahan atas Undang-undang Nomor 23 tahun 2002 tentang perlindungan anak sama

21 Nasir Djamil, Anak Bukan Untuk Di Hukum, (Jakarta: Sinar Grafika, 2013), 8

22 Chandra Gautama. Konvensi Hak Anak Bagi Panduan Jurnalis. (Jakarta: LSPP, 2005), 21

${ }^{23}$ R.Wiyono, Sistem Peradilan Pidana Anak Di Indonesia (Jakarta: sinar grafika, 2016), . 12. dengan frasa "dibawah umur 18 (delapan belas) dalam pasal 1 Konvensi tentang Hak-Hak anak yang telah diratifikasi dengan UU Nomor 5 tahun 1998.

b. Termasuk anak yang masih dalam kandungan.

Untuk memberikan arti dari frasa "Termasuk anak yang masih dalam kandungan" dalam pasal 1 angka 1 Undang-undang Nomor 35 tahun 2014 tentang perlindungan anak agar dikaitkan dengan pasal $2 \mathrm{KUH}$ Perdata yang menyatakan bahwa "anak yang ada dalam kandungan seorang perempuan, dianggap sebagai telah dilahirkan, bilamana kepentingan si anak menghendakinya"

Undang-undang Nomor 11 tahun 2012 tentang sistem perdilan pidana anak adalah sistem mengenai proses penyelesaian perkara anak yang berhadapan dengan hukum. Anak yang berhadapan dengan hukum menurut pasal 1 angka 2 Undangundang Nomor 11 tahun 2012 adalah terdiri atas: $:^{24}$

a. Anak yang berkonflik dengan hukum yang selanjutnya disebut anak adalah anak yang telah berumur 12 (dua belas) tahun, tetapi belum berumur 18 (delapan belas) tahun yang diduga melakukan tindak pidana (pasal 1 angka 3);

b. Anak yang menjadi korban tindak pidana yang selanjutnya disebut anak korban adalah anak yang belum berumur 18 (delapan belas) tahun yang mengalami penderitaan fisik, mental, dan/atau kerugian ekonomi yang disebabkan oleh tindak pidana (pasal 1 angka 4);

c. Anak yang menjadi saksi tindak pidana yang selanjutnya disebut

24 Republik Indonesia, Undang-undang Nomor 11 Tahun 2012 tentang Sistem Peradilan Pidana Anak, bab I, angka 3-5. 
anak saksi adalah anak yang belum berumur 18 (delapan belas) tahun yang dapat memberikan keterangan guna kepentingan penyidikan, penuntutan, dan pemeriksaan di sidang pengadilan tentang suatu perkara pidana yang didengar, dilihat dan/atau dialaminya sendiri (pasal 1 angka 5)

Definisi anak yang ditetapkan perundang-undangan berbeda dengan definisi menurut hukum islam dan hukum adat. Menurut hukum islam dan hukum adat sama-sama menentukan seseorang masih anakanak atau sudah dewasa bukan dari usia anak. ${ }^{25}$ Hal ini karena masingmasing anak berbeda usia untuk mencapai tingkat kedewasaan. Hukum Islam menentukan definisi anak dilihat dari tanda-tanda pada seseorang apakah seseorang itu sudah dewasa atau belum. Artinya seseorang dinyatakan dewasa sebagai anak apabila anak tersebut belum memiliki tanda-tanda yang dimiliki oleh orang dewasa sebagaimana ditentukan dalam hukum Islam.

Hukum Perdata nasional memberikan pengertian sendiri tentang anak dengan istilah "belum dewasa" dan mereka yang berada dalam pengasuhan orang tua dan perwalian. Seperti dalam Pasal 330 KUHPerdata mengatakan bahwa orang belum dewasa adalah mereka yang belum mencapai umur genap 21 (dua puluh satu) tahun dan tidak lebih dahulu telah menikah. Pengertian yang di maksud sama halnya dengan pengaturan yang terdapat dalam Undang-undang Republik Indonesia Nomor 1 Tahun 1974 tentang Perkawinan, Yurisprudensi, Hukum Adat, dan Hukum Islam. Pengertian tentang anak diletakkan sama makna

25 Chandra Gautama. Konvensi Hak Anak Bagi Panduan Jurnalis. (Jakarta: LSPP, 2000), 21 dengan mereka yang belum dewasa, dan seseorang yang belum mencapai usia batas legitimasi hukum (21 Tahun) sebagai subjek hukum atau layaknya subjek hukum normal yang ditentukan oleh perundangundangan. $^{26}$

\section{Konsep Perlindungan Anak}

Perlindungan hukum bagi anak dapat diartikan sebagai upaya perlindungan hukum terhadap berbagai kebebasan dan hak asasi anak (fundamental right and freedom of child) serta berbagai kepentingan yang berhubungan dengan kesejahteraan anak. Jadi, masalah perlindungan hukum bagi anak mencakup lingkup yang sangat luas. ${ }^{27}$ Anak sebagai generasi penerus bangsa perlu mendapatkan perlindungan terutama sekali dari orang tua, masyarakat dan pemerintah dalam rangka mewujudkan generasi yang tangguh dan bermartabat. Anak memiliki peran strategis dalam pembangunan bangsa ke depan. Oleh karenanya, pemerintah dengan berbagai instrumen aturan perundangundangan yang mengatur tentang perlindungan anak dengan tujuan memberikan perlindungan hukum bagi anak.

Salah satu perlindungan hukum yang diberikan pemerintah kepada anak khususnya anak yang berhadapan dengan hukum adalah disahkannya UU Nomor 11 Tahun 2012 tentang Sistem Peradilan Anak. Dalam konteks ke-Acehan telah disahkannya Qanun Nomor 11 Tahun 2008 tentang Perlindungan Anak yang mengatur tentang cara penyelesaian anak yang berhadapan dengan hukum

${ }^{26}$ Maulana Hasan Wadog. Advokasi dan Hukum Perlindungan Anak. (Jakarta: Grasindo. 2008), 2

${ }^{27}$ Mulyadi, Kapita Selekta Sistem Peradilan Pidana, . 1. 
menggunakan

pendekatan kesejahteraan anak melalui diversi. Konsideran huruf (d) UU Nomor 11 Tahun 2012 merumuskan bahwa Undang-Undang Nomor 3 Tahun 1997 tentang Pengadilan Anak sudah tidak sesuai lagi dengan perkembangan dan kebutuhan hukum masyarakat karena belum secara komprehensif memberikan pelindungan kepada anak yang berhadapan dengan hukum sehingga perlu diganti dengan undangundang baru.

Hal ini mengindikasikan bahwa komitmen pemerintah memberikan perlindungan hukum kepada anak semakin serius. Banyaknya kasuskasus anak yang berhadapan dengan hukum yang kemudian berakhir dibalik jeruji besi menjadi perhatian penting. Akibatnya, regulasi yang telah ada yang belum dapat mengakomodasi kepentingan terbaik bagi anak dan lebih cenderung menggunakan pradilan formal dihilangkan dengan disahkannya UU Nomor 11 Tahun 2012. Dalam UU tersebut lebih menekankan pada konsep restoratif justice melalui sistem diversi. Bahkan upaya diversi wajib dilaksanakan pada setiap tingkatan penegak hukum yakni Kepolisian, Kejaksaan dan pada saat pemeriksaan di persidangan Pengadilan.

Penyelenggaraan melalui sistem peradilan pidana anak perlu memperhatikan asas-asas sebagaimana yang diatur dalam Pasal 2 UU Nomor 11 Tahun 2012, yaitu: perlindungan, keadilan, non diskriminasi, kepentingan terbaik bagi anak, penghargaan terhadap pendapat anak, kelangsungan hidup dan tumbuh kembang anak, pembinaan dan pembimbingan anak, proporsional, perampasan kemerdekaan dan pemidanaan sebagai upaya terakhir, dan penghindaran pembalasan ${ }^{28}$.

\section{Sistem Peradilan Pidana Anak \\ Sistem peradilan pidana adalah} sistem pengendalian kejahatan yang terdiri dari lembaga-lembaga kepolisian. Kejaksaan, pengadilan dan permasyarakatan terpidana. ${ }^{29}$ Dikemukakan pula bahwa sistem peradilan pidana (criminal justice system) adalah sistem dalam suatu masyarakat untuk menanggulangi kejahatan. ${ }^{30}$ Menanggulangi diartikan sebagai mengendalikan kejahatan agar berada dalam batas-batas toleransi masyarakat. Pengendalian kejahatan agar masih dalam batas toleransi masyarakat tidak berarti memberikan toleransi terhadap suatu tindak kejahatan tertentu atau membiarkannya untuk terjadi. Toleransi tersebut sebagai suatu kesadaran bahwa kejahatan akan tetap ada selama masih ada manusia di dalam masyarakat. Jadi, dimana ada masyarakat pasti tetap akan ada kejahatan.

Sistem peradilan pidana merupakan suatu jaringan (network) peradilan yang menggunakan hukum pidana sebagai sarana utamanya, baik hukum pidana materiil, hukum pidana formil maupun hukum pelaksnaan pidana. $^{31}$ Namun demikian kelembagaan substansial ini harus dilihat dalam kerangka atau konteks sosial. Sifatnya yang terlalu formal

28 Pasal 2 UU RI Nomor 11 Tahun 2012 Tentang Sistem Peradilan Pidana Anak

${ }^{29}$ Mardjono Reksodiputro, Sistem Peradilan Pidana Indonesia (Melihat Kepada Kejahatan Dan Penegakan Hukum Dalam Batas - Batas Toleransi), (Jakarta: Fakultas Hukum Unversitas Indonesia, 1993), . 1

30 Romli Atmasasmita, Sistem Peradilan Pidana(Criminal Justice System) Perspektif Eksistensialisme Dan Abolisionalisme, (Jakarta: Penerbit Bina Cipta, 1996), . 15.

${ }^{31}$ Muladi, Kapita Selekta Sistem Peradilan Pidana, (Semarang: Badan Penerbit Universitas Diponegoro, 1995), . Viii Dan 18 
apabila dilandasi hanya untuk kepentingan kepastian hukum saja akan membawa kepada ketidakadilan. $^{32}$

Sistem peradilan pidana didefinisikan sebagai sistem dalam masyarakat untuk menanggulangi masalah-masalah kejahatan. Pengertian menanggulangi di sini diartikan sebagai usaha untuk mengendalikan kejahatan agar berada dalam batas-batas toleransi masyarakat. ${ }^{33}$ Artinya melalui pelaksanaan sistem peradilan pidana dapat diwujudkan suatu keteraturan kehidupan bermasyarakat. Sistem ini akan dianggap berhasil manakala keluhan-keluhan dan laporan masyarakat terhadap tindak pidana yang dilakukan mulai berkurang.

M. Ali Zaidan menyimpulkan tiga tujuan dari sistem peradilan pidana, yaitu: $:^{34}$

a. Mencegah masyarakat menjadi korban kejahatan

b. Menyelesaikan kasus kejahatan yang terjadi sehingga masyarakat puas, bahwa keadilan telah ditegakkan dan yang bersalah dipidana, dan

c. Mengusahakan agar mereka yang pernah melakukan kejahatan tidak mengulangi lagi kejahatannya.

Sistem peradilan pidana merupakan jaringan (network) peradilan yang menggunakan hukum pidana sebagai sarana utamanya, baik hukum pidana substansial, hukum pidana formal maupun pelaksanaan pidana. Sistem peradilan pidana mempunyai dimensi fungsional ganda, di satu pihak berfungsi sebagai sarana

\footnotetext{
${ }^{32}$ Muladi, Kapita Selekta Sistem Peradilan Pidana, . 4

33 Muhammad Ali Zaidan, Мепији Pembaharuan Hukum Pidana. . 114.

34 Muhammad Ali Zaidan, Menuju Pembaharuan Hukum Pidana, . 114.
}

masyarakat untuk menahan dan mengendalikan kejahatan pada tingkat tertentu.

Sistem peradilan pidana dan penjatuhan pidana sebagai bentuk penyelesaian konflik bukan untuk membalas. Pidana dan pemidanaan adalah bentuk pertanggungjawaban pelanggar terhadap akibat (dampak) perbuatan melanggar hukum pidana dan orang yang dirugikan secara langsung akibat kejahatan (korban) bersifat aktif untuk menyelesaikan konflik. Perlindungan hukum terhadap korban selama ini didasarkan pada KUHP sebagai hukum materiil, dengan menggunakan KUHAP sebagai hukum acara ${ }^{35}$.

Sistem peradilan pidana merupakan serangkaian perwujudan dari kekuasaan menegakkan hukum pidana yang terdiri dari empat subsistem, yaitu:

a. Kekuasaan penyidikan (oleh lembaga/badan penyidik)

b. Kekuasaan penuntutan (oleh badan/lembaga penuntut umum)

c. Kekuasaan mengadili dan menjatuhkan putusan/pidana (oleh badan pengadila)

d. Kekuasaan pelaksanaan putusan/pidana (oleh badan/aparat pelaksana/eksekusi).

Lembaga penegak hukum tersebut memiliki keterkaitan yang tidak bisa dipisahkan satu dengan lainnya dan harus dilalui berdasarkan tahapannya masing-masing. Suatu peristiwa yang diduga adanya tindak pidana tidak boleh langsung ditangani oleh Kejaksaan dan Pengadilan. Akan tetapi harus dilakukan penyidikan terlebih dahulu oleh kepolisian. Menurut Lilik Mulyadi, suatu berkas perkara hasil penyidikan dinyatakan

35 Siswanto Sunarso, Victimologi dalam Sistem Peradilan Pidana, cet. 1, (Jakarta: Sinar Grafika, 2012), . 48 
telah lengkap formal dan kelengkapan materil. Kelengkapan berkas perkara hasil penyidikan hendaknya harus berisikan antara lain hal-hal sebagai berikut: ${ }^{36}$

a. Identitas lengkap tersangka, sebagaimana ketentuan Pasal 143 Ayat (2) huruf A KUHAP.

b. Surat izin ketua Pengadilan Negeri setempat apabila dilakukan penggeledahan ataupun penyitaan (Pasal 33, Pasal 38 KUHAP)

c. Adanya surat khusus ketua pengadilan negeri setempat apabila pemeriksaan surat dilakukan (Pasal 47 KUHAP)

d. Kalau tindak pidana tersebut adalah delik aduan (krachtdelicten), harus ada surat pengaduan dari orang yang berhak;

e. Penyidik/penyidik pembantu hendaknya harus memenuhi persyaratan tertentu sebagaimana ditentukan Pasal 2 Ayat (1), (2), Pasal 3 Ayat (1), (2) Peraturan Pemerintah.

f. Pembuatan Berita Acara harus sesuai dengan ketentuan Pasal 75 KUHAP, apabila dilakukan pemeriksaan tersangka, penangkapan, penahanan, penyitaan dan lain sebagainya dan ditandatangani oleh orang yang berhak.

Kelengkapan materil agar berkas perkara memenuhi persyaratan dilimpahkan ke pengadilan negeri antara lain haruslah memenuhi ketentuan adanya alat-alat bukti sebagaimana diatur pada Pasal 183, 184 KUHAP serta adanya uraian secara cermat, jelas dan lengkap terhadap tindak pidana yang disangkakan dengan menyebutkan

36 Lilik Mulyadi, Hukum Acara Pidana Normatif, Teoritis, Praktik dan Permasalahannya, (Bandung: PT. Alumni, 2007), . 137-138. tentang locus delicti dan tempus delicti (Pasal 143 Ayat (2) huruf b KUHAP). Setelah berkas perkara dinyatakan lengkap (P-21), Jaksa Penuntut Umum kemudian membuat dan dakwaan dan melimpahkan kepada Pengadilan Negeri yang memiliki wilayah yurisdiksi dalam mengadili kasus tersebut ${ }^{37}$. Setelah Penuntut Umum mengajukan dakwaan, maka perkara tersebut sudah dapat diadili oleh majelis hakim yang sudah ditetapkan oleh Ketua Pengadilan untuk mengadili dan memutuskan kasus tersebut.

Pasal 1 Angka 1 UU Nomor 11 Tahun 2012 menyatakan Sistem Peradilan Pidana Anak adalah keseluruhan proses penyelesaian perkara Anak yang berhadapan dengan hukum, mulai tahap penyelidikan sampai dengan tahap pembimbingan setelah menjalani pidana. Penyelesaian perkara anak yang berhadapan dengan hukum juga diawali dengan penyidikan di tingkat kepolisian, tahap penuntutan di Kejaksaan dan pada tahap persidangan di pengadilan. Jadi, semua tahapan tersebut harus dilalui jika seorang anak diselesaikan melalui pendekatan litigasi.

Pada dasarnya memang harus melalui tahapan-tahapan tersebut, akan tetapi berdasarkan UU Sistem Peradilan Pidana Anak diberikan kepada setiap setiap tingkatan, yakni Kepolisian, Kejaksaan dan Pengadilan untuk melakukan diversi dengan melibatkan pelaku anak, korban, orang tua anak, orang tua korban, masyarakat, penasehat hukum.

Kata terpenting dalam ketentuan diatas adalah "mengadili". Perbuatan mengadili berintikan mewujudkan keadilan, hakim melakukan kegiatan dan tindakan-tindakan. Pertama-tama 
menelaah lebih dahulu kebenaran peristiwa yang diajukan kepadanya, setelah itu mempertimbangkan dengan memberi penilaian atas peristiwa itu, serta menghubungkannya dengan hukum yang berlaku kemudian memberikan kesimpulan dan menjatuhkan putusan terhadap peristiwa tersebut. Dalam mengadili, hakim berusaha kembali menegakan hukum yang dilanggar. Salah satu usaha penegakan hukum itu adalah melalui peradilan anak, sebagai suatu usaha perlindungan anak untuk mendidik anak tanpa mengabaikan tegaknya keadilan. ${ }^{38}$

Peradilan anak diselenggarakan dengan tujuan untuk mendidik kembali dan memperbaiki siakp dan perilaku anak sehingga ia dapat meninggalkan perilaku buruk yang selam ini telah ia lakukan. Perlindungan anak, yang diusahakan dengan memberikan bimbingan/pendidikan dalam rangka rehabilitasi dan resosialisasi, adalah menjadi landasan peradilan anak.

Pasal 1 butir 1 a UU No. 4 Tahun 1979 tentang Kesejahteraan Anak menentukan: "Kesejahteraan Anak adalah suatu tata kehidupan dan penghidupan anak yang dapat menjamin pertumbuhan dan perkembangnnya dengan wajar baik secara rohani, jasmani maupun sosial".

Mewujudkan kesejahteraan anak, menegakan keadilan merupakan tugas pokok badan peradilan menurut undang-undang. Peradilan tidak hanya mengutamakan penjatuhan pidana saja, tetapi juga perlindungan bagi masa depan anak merupakan sasaran yang dicapai oleg peradilan pidana anak.

38 Maidin Gultom. Perlindungan Hukum Terhadap Anak Dalam Sistem Peradilan Pidana Anak Di Indonesia. (Bandung: PT. Refika Aditama, 2010), . 77

\section{Kesimpulan}

Penanggulangan anak sebagai korban tindak pidana dalam sistem peradilan pidana di Indonesia harus di dilakukan dengan menggunakan pendekatan restorative juctice, yaitu proses penyelesaian yang dilakukan di luar sistem peradilan pidana (criminal justice system) dengan melibatkan korban, pelaku, keluarga korban dan pelaku, masyarakat serta pihak-pihak yang berkepentingan dengan suatu tindak pidana yang terjadi untuk mencapai kesepakatan dan penyelesaian. Kebijakan ini berangkat dari asumsi bahwa tanggapan atau reaksi terhadap pelaku delinkuensi anak tidak akan efektif tanpa adanya kerjasama dan keterlibatan dari korban, pelaku dan masyarakat. Prinsip yang menjadi dasar adalah bahwa keadilan paling baik terlayani, apabila setiap pihak menerima perhatian secara adil dan seimbang, aktif dilibatkan dalam proses peradilan dan memperoleh keuntungan secara memadai dari interaksi mereka dengan sistem peradilan anak.

Perlindungan hukum terhadap anak sebagai korban di dalam sistem peradilan pidana yang bersifat restorative justice dalam menangani persoalan-persoalan perkara anak yang berkonflik dengan hukum, maka perlu memperhatikan beberapa hal sebagai berikut: (a). Harmonisasi instrumen hukum nasional yang mengacu kepada standar instrumen internasional tentang perlindungan anak. Harmonisasi hukum ini dilakukan karena begitu banyaknya peraturan perundangundangan di Indonesia yang mengatur tentang anak, disamping itu Indonesia merupakan bagian dari masyarakat internasional yang terikat dengan sejumlah konvensi maupun instrument hukum internasional lainnya yang bertujuan untuk memberikan perlindungan anak dalam rangka meningkatkan derajat, martabat dan kesejahteraan anak. (b) Batas Usia 
penahanan anak dan pertanggungjawaban pidana anak yang dapat diajukan ke sidang anak. Perbedaan batas usia minimal dan maksimal pertanggungjawaban pidana tidak hanya berdampak terhadap perbedaan penanganan dari sistem peradilan pidana anak, tetapi juga berhubungan dengan organisasi-organisasi dan institusi-institusi seperti pekerja sosial dan pelayanan anak. (c) Konsep diversi, yaitu mekanisme yang dimaksudkan untuk mengkongkritkan pendekatan keadilan yang restoratif.

\section{DAFTAR PUSTAKA}

Achmad Ali, Wiwie Heryani, Menjelajahi Kajian Empiris terhadap Hukum, Jakarta: Kencana Prenada Media Group, 2012

Dewi dan Fatahillah, Mediasi Penal Penerapan Restorative Justice di Pengadilan Anak Indonesia, Depok: Indie Publishinh, 2011

Eriyantouw Wahid, Keadilan Restoratif Justice dan Peradilan Konvensional Dalam Hukum Pidana, Jakarta: Trisakti, 2009

Gempur Santoso, Metodologi Penelitian Kuantitatif \& kuanlitatif, Jakarta: Prestasi Pustaka Publisher, 2005

Lilik Mulyadi, Hukum Acara Pidana Normatif, Teoritis, Praktik dan Permasalahannya, Bandung: PT. Alumni, 2007

Muhammad Ali Zaidan, Menuju Pembaharuan Hukum Pidana, Jakarta: Sinar Grafika, 2015

Muladi, Kapita Selekta Hukum Pidana, Semarang: Universitas Diponegoro, 1995

Nurnaningsih Amriani, "Penanganan Perkara Anak Melalui Konsep Diversi dan Restoratif Justice", Majalah Hukum Varia Peradilan, Nomor 323, Jakarta: IKAHI, 2012

Romli atmasasmita, Peradilan Anak Di Indonesia, Bandung: Mandar Maju, 1997
S. Atalim, Keadilan Restoratif sebagai Kritik Inheren terhadap Pengadilan Legal-Konvensional", Jurnal Rechts Vinding Media Pembinaan Hukum Nasional, Vol. 2 No. 2, Jakarta: Pusat Penelitian dan Pengembangan Sistem Hukum Nasional, 2013

Septa Candra, Restoratif Justice: Suatu Tinjauan terhadap Pembaharuan Hukum Pidana di Indonesia, "Jurnal RechtsVinding Media Pembinaan Hukum Nasional, Vol. 2 No. 2, Jakarta: Pusat Penelitian dan Pengembangan Sistem Hukum Nasional, 2013, hlm. 264.

Siswanto Sunarso, Victimologi dalam Sistem Peradilan Pidana, Jakarta: Sinar Grafika, 2012.

Soerjono Soekanto, Pengantar Penelitian hukum, Jakarta: UI Press, 1987

UU RI Nomor 11 Tahun 2012 Tentang Sistem Peradilan Pidana Anak 